\title{
Librarianship as a Christian Vocation
}

by Ben Myers

This paper provides a theological account of librarianship as a Christian vocation. Drawing on the eccentric Russian librarian-theologian Nikolai Fedorov, I argue that the library is a catholic and ecumenical institution, and that the vocation of librarians is to make connections wherever knowledge remains divided. The fundamental connection with which librarianship is concerned is the temporal connection between past and future: the librarian's calling is to hold past and future together, and in this respect the Christian librarian's vocation is an abridgement of the calling of the whole people of God.

\section{Librarianship as a Christian Vocation}

I. The Joy of Libraries

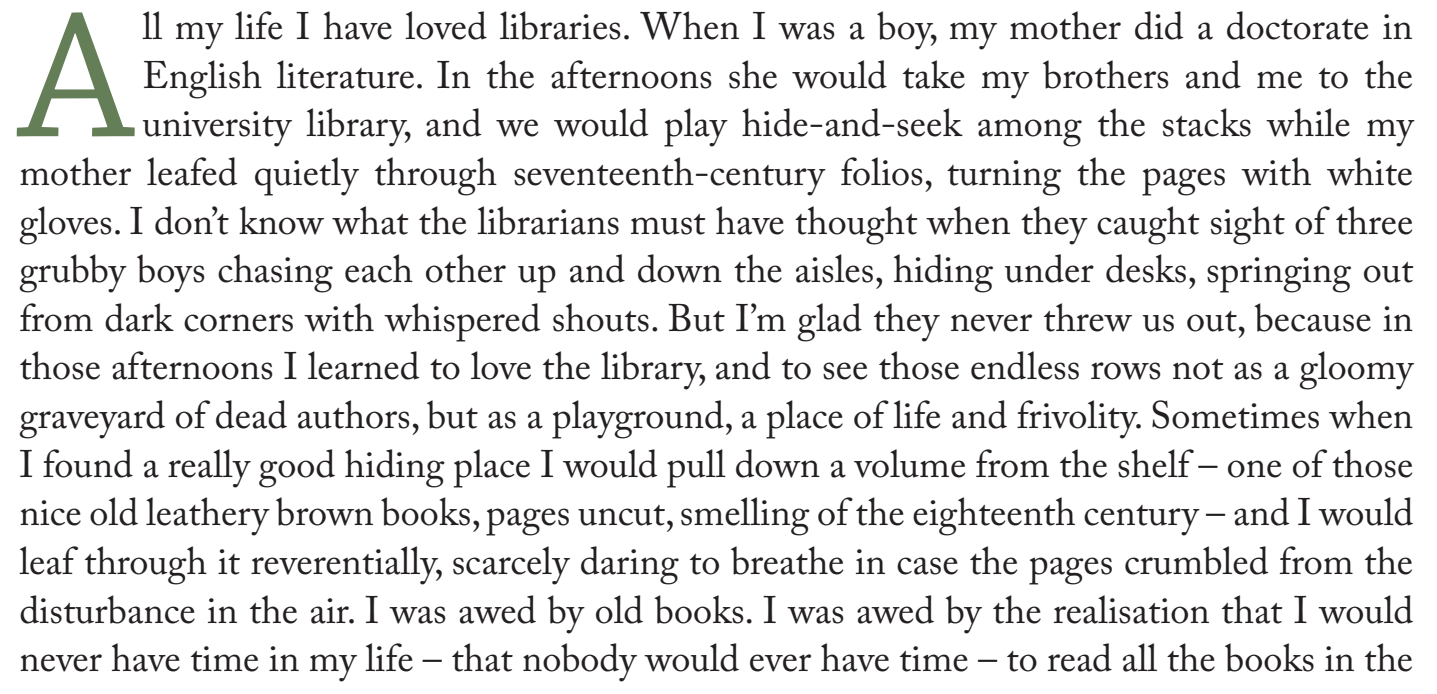




\section{"I didn't know it}

at the time, but

the peace of those

afternoons in

the library was a

Christian peace;

the happiness

of my brothers

and me as we

scampered about

was Christian joy,

the joy of time, the

joy of running down

the aisles between

the future and the

past." library. That is how I came to see that there are things that transcend the limits of a lifetime, things rooted deep in time that will outlast me, that will go on standing at attention long after I'm gone. It was a consoling thought. I have always been troubled by the vulnerability of human life, and it felt safe and reassuring to be there amid those lovingly organised stacks, slipping the book carefully back into its place, pages still uncut, and wondering how long it would be twenty years? fifty? - before ever that book was touched again by human hands. And when someone finally cut the pages and read every word, what mysteries might be waiting for them? What secrets might be revealed?

I was ten years old, a boy. I had no membership, no library card, no research interests. I could scarcely reach the drawers of the card catalogue. I was not, in short, a user of the library. Yet I was a visitor to that library, one of the happiest it ever had. It was those afternoon hide-and-seek visits with my brothers that taught me that the library is a place of wonder, a place where I felt snuggled in tight between the past and the future. The same book that I held had been handled hundreds of years before I was born, and would one day, after I was gone, be touched again.

Here, in the library, time is so close that you can almost reach out and touch the past with one hand and the future with another.

In the modern world, we experience time as a curse. In Waiting for Godot, Samuel Beckett said that we 'give birth astride of a grave, the light gleams an instant, then it's night once more.' Time is an intolerable burden, an insult against the human spirit, because it reaps us away too quickly and too soon. But it was the library that taught me the true and Christian doctrine of time: that time is not a curse but a blessing. Hiding there among the rows of shelves, the benevolent smell of pages and old dust, I knew that I was somewhere safe and good. Handling those old books, I loved time - or rather, I felt loved by time, as though that book had been waiting through silent centuries just for this moment, just for me. I didn't know it at the time, but the peace of those afternoons in the library was a Christian peace; the happiness of my brothers and me as we scampered about was Christian joy, the joy of time, the joy of running down the aisles between the future and the past.

When I grew older I thought of becoming a librarian. I made the appropriate inquiries. But I was informed that my lack of punctuality, my phobia of discipline, my indifference to order and organisation, my preference for dogs over cats, and indeed my general air of slovenliness all disqualified me from the noble vocation of librarianship. So instead I became a teacher and a theologian, since that seemed a good enough way of spending most of my time hanging about in the library.

I did, however, get to spend one year of my life working in a library. It was at the University of Queensland about a decade ago. After I'd finished my studies I was recruited to help develop a bibliographic 


\section{"They became detectives}

themselves, bloodhounds on

the scent of the truth, animated by the violence and joy of the chase. Bibliographic

mysteries were traced relentlessly back to their origins; puzzles were solved; indignation and horror were expressed; faces normally calm and composed would be mottled red." database for Australian literature. ${ }^{1}$ My desk was in the Fryer Library, right there on the seventh floor among the archives and rare books, high above the round room where the leisurely professors and beleaguered postgraduates came to read. I worked there with a team of librarians. Our job was simple: to create bibliographic records for every item of Australian literature ever published - everything from books and journals to self-published memoirs, satirical newspaper columns, page-three poems in the Townsville Daily Bulletin. Existing records could under no circumstances be trusted. Every item had to be viewed with our own eyes, the records checked and verified. Where multiple editions of a work exist, every edition had to be viewed and described in separate records. Not only the basic bibliographic details either; each record was tagged with keywords describing its genre, content, and relation to other works or writers. So it was that I spent a year analysing shelf after shelf of the Fryer Library's holdings, checking facts and comparing notes with librarians from around the country, corresponding with the next of kin of obscure inaccessible authors, compiling lists of catalogue corrections. And, of course, reading. Because in order to describe the contents of an item, you had to look at it. Which is why, to this day, I have a surprisingly good general knowledge of Australian writers whose names begin with the letters K, L, and the early Ms. And why I have the unshakable conviction that you can never trust a catalogue record until you have seen the alleged item with your own eyes.

Also it is how I came to know that there is a strange, clean joy in the act of cataloguing, and of getting a record right.

What really made an impression on me, though, were the librarians at the desks next to mine. At a first glance they seemed mild-mannered enough. They brought salads for lunch in tupperware containers. They were respectful, softspoken, and well mannered. They read detective novels and did crossword puzzles. But a cataloguing error, an unsolved bibliographic anomaly, a confusion of names in the catalogue, the discovery of an author's pseudonym - an event of that order could trigger the most extraordinary passions. They became detectives themselves, bloodhounds on the scent of the truth, animated by the violence and joy of the chase. Bibliographic mysteries were traced relentlessly back to their origins; puzzles were solved; indignation and horror were expressed; faces normally calm and composed would be mottled red. And then we would turn back to our desks and get started on the next thing.

Here was a side of librarians I had never seen before. It was something hungry and emphatic. It was conviction, a horror of error, a love of truth. That was when I came to understand - and here I come to my point - that librarianship is not a job but a vocation.

To speak of a vocation is to say that it is more than just something you do; it is a particular way of being alive.

To speak of a vocation is to speak of a response to a call. The

1 AustLit: The Australian Literature Resource: www.austlit.edu.au 


\section{"But when a list}

was given to

Fedorov, the reader

would be given

the requested

items, plus many

additional books

which he had not

asked for or even

heard of. These

would turn out

to be important

- sometimes the

most important -

contributions to the

research." librarian has heard something. She has responded to it. And she is strangely alive because of what she has heard.

What, then, is this calling to librarianship? What is it that the librarian hears? What is it to which the librarian is responding? Those are the questions that I want to explore in this paper. And I will begin by turning to the story of a great librarian who also happened to be a theologian: the Russian librarian Nikolai Fedorov.

II. Nikolai Fedorov (1828-1903): Utopian Librarianship

Nikolai Fedorov was never formally educated; he never taught in a university; he tried very hard to avoid publishing any of his thoughts; he lived a modest life, working as a librarian and spending most of his time in the library; and yet some scholars regard him as one of the most important figures of modern Russian intellectual history. Leo Tolstoy said of him, 'I am proud to have lived at the same time as such a man'. Vladimir Solovyov, the most influential Russian philosopher of the time, claimed to be Fedorov's disciple. Dostoevsky's novel The Brothers Karamazov bears Fedorov's influence. A later novelist, Boris Pasternak, used Fedorov as the basis of a major character in Dr Zhivago. One of the founders of space travel and rocket science, Konstantin Tsiolkovsky, considered Fedorov his most important teacher. ${ }^{2}$

How did a modest librarian come to exercise such a vast and diverse influence on Russian culture?

Fedorov began working as an assistant in the Chertkov Library in Moscow in 1869, after many years of wandering about the small towns and villages of Russia. In 1874 he became a desk clerk, and later a cataloguer, in Moscow's first public library, the Rumyantsev Museum, where he remained for a quarter of a century. The Rumyantsev would later become the Russian State Library, today one of the largest collections in the world. In Fedorov's time, the collection comprised 85,000 books plus 18,000 additional unbound items. Fedorov was said to know not only the title and location of every item in the library, but also its contents. When researchers came to the library, they would make a list of requested books from the card catalogue, and one of the librarians would bring the requested items and place them on a desk in the reading room. But when a list was given to Fedorov, the reader would be given the requested items, plus many additional books which he had not asked for or even heard of. These would turn out to be important - sometimes the most important - contributions to the research. By looking at a list of titles, Fedorov would immediately understand the nature of the research, and his intimate knowledge of the collection would allow

2 For surveys of Fedorov's life and ideas, see George M. Young, Jr., Nikolai F. Federov: An Introduction (Belmont, MA: Nordland Publishing Company, 1979); George M. Young, The Russian Cosmists: The Esoteric Futurism of Nikolai Fedorov and His Followers (Oxford: Oxford University Press, 2012); and Donald Nicholl, Triumphs of the Spirit in Russia (London: Darton, Longman and Todd, 1997), 67118. 
"Tolstoy gestured to the piles of books and remarked

flippantly: 'So many stupid things are

written; it should

all be burned!'

Fedorov gripped his head in his hands, stunned. He could

forgive Tolstoy for his faulty religious ideas; he could forgive him for his bad philosophy; but he never forgave him for speaking that way about the library." him to make startlingly apposite connections. Here is how one of his contemporaries described it: "If you asked him for several books, he would unerringly define the subject of your research, knowing beforehand, in all details, the entire contents of every book you ordered, and there was not one question or problem which was not of profound interest to him.' ${ }^{3}$

He performed this service for readers across the whole spectrum of disciplines, so that before long the leading figures of Russian intellectual life were seeking out Fedorov's advice. His humble desk in the catalogue room was described as 'the spiritual centre of Moscow'. One visitor to the library described arriving in the catalogue room to the sight of 'a dozen or so people, mostly students, crowding around the librarian. ${ }^{4}$ This is where Tolstoy and Solovyov and so many Russian intellectuals came to visit Fedorov, to ask him what to read, or to listen to his ideas. After hours, and on Sundays, Fedorov would stay behind to work. When word got out, scholars began to visit him at these times, so that the reading room became the venue for informal after-hours seminars.

On payday, a line of people could be seen waiting outside the library, because Fedorov gave away most of his pay to the students and janitors at the library. He had accepted the job on the condition that he receive a minimum wage, and that his wage would never be raised. He lived in a tiny room above a grocery store and lived on cups of tea and leftovers of stale bread. He had only one change of clothes, and in the street was often mistaken for a beggar. His room had no furniture except for a hard trunk where he slept, using newspapers for a blanket. When some insistent friends got him a bed and a pillow, they came next week to find that he had already given them away. He belongs to the great tradition of Russian asceticism - yet he was by no means a gloomy person. His little unfurnished room was always full of visitors, and when he walked to the library he would have sweets in his pockets for the children. If he had any money in his pocket he would try hard to give it all away before the end of the day. He had a morbid fear that he might be found dead one day with a couple of coins still in his pocket: an appalling thought. Any time he was given a book he donated it immediately to the library. And he believed very firmly that every published thing should be preserved; it was a moral imperative that no printed page should perish. One day when Tolstoy was with him in the library, Tolstoy gestured to the piles of books and remarked flippantly: 'So many stupid things are written; it should all be burned!' Fedorov gripped his head in his hands, stunned. He could forgive Tolstoy for his faulty religious ideas; he could forgive him for his bad philosophy; but he never forgave him for speaking that way about the library. ${ }^{5}$

Fedorov's devotion to the library arose from what might be

3 Young, Nikolai Federov, 28-29.

4 Nicholl, Triumphs of the Spirit in Russia, 75.

5 Young, Nikolai Federov, 65. 
"He also proposed that science - based on the technology of the telegraph

\section{- might be used}

\section{to connect the}

\section{world's libraries,}

so that eventually

all the world's

information would

be freely available

to everyone. All the

voices of the past

would be given a

medium in which to

speak; all people of

the present would

be able to hear

them." called a theology of librarianship. Here is how one scholar describes Fedorov's understanding of his work:

$[\mathrm{He}]$ regarded librarianship as a sacred calling because for him a library was not a 'book graveyard' as he said, but the presence of many human beings, for 'behind every book is a person'. And he was serving the persons behind the books just as much as he was serving the visitors to the library in search of the books. ${ }^{6}$

In Fedorov's view, there is no gulf between the present and the past. In Christ, all who have died are living still. They are not consigned to the oblivion of history. They are a cloud of witnesses. The library is not a memorial to the past; it is a home in which the past lives. As Fedorov also said of his other favourite institution, the museum: '[it] is not a collection of things, but a community of persons.' ${ }^{7}$ Fedorov's own vocation was to offer himself in service to such a community of persons. He puts himself at their disposal. He was responsible to them. He was the point of connection between the living voices of the past and the living library users of the present.

Fedorov had all sorts of practical and not-so-practical ideas about how to cultivate and deepen this connection. One of his schemes was to expand the existing catalogue system so that it would include not only author, title, and call number, but also a summary of the contents of each item. He also proposed that science - based on the technology of the telegraph - might be used to connect the world's libraries, so that eventually all the world's information would be freely available to everyone. All the voices of the past would be given a medium in which to speak; all people of the present would be able to hear them. Thus the library would become an engine of social transformation, demolishing the division between rich and poor, as well as, to Fedorov's mind, the much more fundamental division between educated and uneducated. In the nineteenth century, the notion that technology could be used to connect the world's libraries must have sounded hopelessly utopian. On a more practical level, Fedorov tried to organise exchanges of material between libraries of different countries. He argued that universities were putting all their knowledge into the service of war, and he believed libraries could resist such militarisation of knowledge by striving instead for the free sharing of information across national boundaries.

I have been focusing here on Fedorov's understanding of librarianship, and have only hinted at the broader outlines of his theological system - a system that is perhaps one of the strangest and most eccentric in the history of Christian thought. He envisaged a global project, which he called 'the common task', in which all the world's knowledge would be united for the purpose of controlling the weather and other environmental conditions, in order to eradicate hunger and to create a unified global society. This unification of the

6 Nicholl, Triumphs of the Spirit in Russia, 74.

7 Ibid., 114. 


\section{"He saw copyright}

as an insidious

evil, that corrupts

the mind, turning

one's thoughts

into private

property that can

be sold for profit.

When one of his

followers insisted

on publishing some

of his writings, it

was only on the

condition that it

could be given away

freely to anyone." world's knowledge would lead to space travel and the colonisation of other planets. Finally, the global scientific endeavour would develop the technological capacity to resurrect the dead, so that death itself would be abolished. (That's why space travel was important; once you've resurrected every person who ever lived, the world will be grossly overpopulated and you'll need to start colonising other planets.) That was the theological idea that inspired the young Tsiolkovsky, who spent three years with Fedorov in the library before he went on to become a pioneer of rocket science. ${ }^{8}$ Though Fedorov's ideas were well known at the time, he resisted having his thoughts published, because he was strongly opposed to the idea of copyright. He saw copyright as an insidious evil, that corrupts the mind, turning one's thoughts into private property that can be sold for profit. When one of his followers insisted on publishing some of his writings, it was only on the condition that it could be given away freely to anyone.

As strange as Fedorov's broader vision might sound, what is really behind his thought is a theme that was quite central to the tradition of modern Russian Orthodox theology: the theme of disconnection. Like so many other Russian thinkers, Fedorov saw the fallenness of the world manifest in its 'disrelatedness', as he called it. ${ }^{9}$ Everything is divided - rich and poor, educated and uneducated, church and world, parents and children, past and present. Redemption is about making connections, putting things back together, overcoming all those divisions and separations. What Fedorov longed for was an 'all-embracing reunion' between the present and the past; on that day, he said, 'all will be related, nothing will be alien'. ${ }^{10}$ And as I have indicated, he saw the institution of the library as one of the engines of that great social transformation.

\section{The Catholicity of the Library: Making Connections}

I have described the views of Nikolai Fedorov because I think, for all his eccentricity, he helps to bring the question of the librarian's vocation into a surprisingly clear focus. At so many different points, Fedorov stresses that the library is an institution that makes connections.

If we simply ask, 'What is a library?', it doesn't turn out to be a very helpful question. For the library's significance does not lie in itself. The point of the library is that it establishes an extraordinarily complex web of connections. It is important because of what it stands between. The library is a point of connection between persons, traditions, institutions, and discourses. There are connections between users and information, between publishers and readers, between scholars and their research, between material print culture and virtual culture, and between various members of the reading public.

8 On Fedorov's influence on Tsiolkovsky and other Russian scientists, see

Young, The Russian Cosmists, chapter 9.

9 Nicholl, Triumphs of the Spirit in Russia, 81.

10 Federov, as cited in Nicholl, Triumphs of the Spirit in Russia, 110. 


\section{"If the librarian's}

\section{vocation is to}

make connections

- if the library is

less a thing-in-

itself than a point

of connection

between disparate

discourses, persons,

and institutions

- then one might

also say that the

librarian is a person

called to stand in

between."
The library is a point of connection between different languages and traditions, between institutions like churches, seminaries, dioceses, presbyteries, and so forth. And consider the way different cultures are connected in the institution of the library. The library today is an engine of cultural exchange, of the whole process whereby multiple cultures are drawn into a shared discourse.

All this can be summed up in Jaroslav Pelikan's observation that 'there is nothing so ecumenical as the library'. ${ }^{11}$ The library is an engine of universality - literally, 'catholicity'. This is the insight that underlies all that Fedorov has to say about librarianship. The librarian has a vocation to catholicity. The librarian is called to overcome barriers and to make connections.

As I have noted, Fedorov is especially animated when it comes to the division between educated and uneducated, because he sees this as the deeper and more pernicious division underlying the divide between rich and poor. Libraries today are uniquely poised to overcome this division, especially through the creation of open-access digital repositories that can be accessed by anyone with a computer. The same texts and traditions that were once reserved to a privileged elite class are now increasingly becoming the common property of the world. I am thinking, for instance, of a project like the Digital Public Library of America, a massive open-access database that will include, and make freely available, the entire contents of the Library of Congress and other major American collections. This would have to rank as one of the most expansively 'catholic' intellectual projects ever undertaken; and we could easily forget that the whole thing is being driven by librarians. When librarians began to realise that Google's monopoly on digitised books could lead eventually to restricted access and inflated subscription costs, their ire was roused: for the librarian's vocation is to seek catholicity, to abolish the divide between those who have information and those who don't. And so the librarians of America are looking set to out-google Google by creating a vastly larger repository of texts, and by giving free access to anyone who wants it. ${ }^{12}$

If the librarian's vocation is to make connections - if the library is less a thing-in-itself than a point of connection between disparate discourses, persons, and institutions - then one might also say that the librarian is a person called to stand in between. The librarian occupies the place in between, wherever there are ruptures or divisions that need to be overcome - and by standing in that place, the librarian bridges the gap, makes the connection, establishes another point on an always-expanding web. Curiously, I think academics are often reluctant to bridge the gap between educated and uneducated;

11 Jaroslav Pelikan, The Idea of the University: A Reexamination (New Haven:

Yale University Press, 1992), 116.

12 See Robert Darnton, 'A Digital Library Better Than Google's,' The

New York Times (March 23, 2011): http://www.nytimes.com/2011/03/24/ opinion/24darnton.html. 
"For it is the

vocation of the

librarian - and

of the institution

of the library - to

occupy a position

between past and

future.... The

librarian abhors

conservatism, since

a mere preservation

of the past would

aim to protect

the past from the

present instead of

making the past

available. And in

equal measure the

librarian abhors

revolution, the

abolition of the

past for the sake of

some blank-slated

future, a future

projected on to

empty shelves." the professor has a vested interest in cultural elitism. Yet when we look more closely at that gap, we see somebody standing there: it is the librarian, standing in between and making a connection. In this matter of providing access to knowledge (and, just as important, promoting basic skills so that knowledge can be accessed), librarians today are generally miles ahead of scholars and churches and universities. But eventually the rest of us will catch up, because now a connection has been made.

\section{The Catholicity of Time: Connecting Past and Future}

That is a sketch of some of the ways in which the librarian makes connections. But there is another point of connection still more important. For it is the vocation of the librarian - and of the institution of the library - to occupy a position between past and future. Here again, we are back to Fedorov, with his enormous sense of responsibility towards the living voices of the past. Librarians place themselves between past and future. They allow themselves to be a point of connection spanning time itself, denying any absolute gulf between yesterday, tomorrow, and today. This connection in time, I suggest, is right at the heart of the librarian's vocation. It is the one central connection from which all the others branch out.

It is for this reason that the librarian resists both a reactionary fixation on the past and a knee-jerk fixation on the future. The librarian abhors conservatism, since a mere preservation of the past would aim to protect the past from the present instead of making the past available. And in equal measure the librarian abhors revolution, the abolition of the past for the sake of some blank-slated future, a future projected on to empty shelves. The librarian conserves the past for the sake of the future; the librarian innovates for the sake of the past. Again, scholars and universities - with their propensity towards either a moribund conservatism or a vapid radicalism compare very unfavourably with librarians on this score. The library is nothing else than the institutionalisation of a catholic vision of time: of past and future holding hands. The remarkable capacity of librarians for constant change and reinvention springs from a deep commitment to what has been received from the hand of the past. To put it in Fedorov's terms, just because every book is really a person, the librarian insists on allowing that person to be heard. Digitisation and the provision of electronic texts for distance users are particularly striking instances of such responsibility; but even considerations of space for reading and the motivation to make catalogues more integrative and user-friendly spring from this commitment to a living connection between past and future.

If you were answerable only to the past, you could lock yourself away in the collection and forget about the users; if you were answerable only to the future, you could throw away the key and let others do whatever they like with the collection. The vocation of the librarian is always to resist both these temptations to apostasy.

V. The Catholicity of Vocation: Christian Librarianship 
"I have suggested that the library is a catholic and ecumenical institution, and that librarians have a vocation to make connections wherever

knowledge remains divided.

And I believe

the continuing

vitality of the

Christian tradition

will depend

in part on the

faithful vocation

of Christian

librarians."
I have suggested that the library is a catholic and ecumenical institution, and that librarians have a vocation to make connections wherever knowledge remains divided. And I believe the continuing vitality of the Christian tradition will depend in part on the faithful vocation of Christian librarians.

But it would be a mistake to conclude therefore that there is something qualitatively unique about the vocation of librarians - that the librarian alone stands in this tension between past and present, or that the librarian alone takes responsibility for the catholicity of truth.

As a matter of fact, everything that has been said about the vocation of librarianship should be applied to the Christian church as a whole. Here is the curious thing. For Christians, there is no qualitatively distinct human vocation, no absolutely unique individual calling. Within the church there is no vocation that stands lonely and remote, distinct from the vocation of the people of God as a whole. Every Christian vocation is just a particular way of crystallising the vocation of the whole people of God. Every individual Christian calling is a microcosm of a call addressed to the whole company of believers.

The vocation of ordained ministry, for example, is in no sense qualitatively distinct from the vocation of the church. The whole church is gathered around Christ, representing a renewed humanity in Christ's presence; and the whole church is sent to bear Christ's witness to the world, standing as Christ's ambassadors in the presence of other human beings. The whole nature of the church is encompassed in the dual representation of priestly ministry: representing the world to Christ, and Christ to the world. The priest, the pastor, the minister is simply a person in whom the vocation of the whole church is crystallised, in whom the vocation of all believers has become explicit and visible and articulate. That is why ordained ministry is essential to the church's continuing vitality; without it, we might forget what it is that all of us are called to be and to do, both in relation to Christ and in relation to the world. Priests are essential just because the church is essential.

Another example: there is, in the church, a calling to something called theological education. It is a sacred and serious calling - this business of minding our speech, both in what we say to God in prayer and in what we say to one another in witness. But is this calling distinct from the vocation of the church as a whole? Do theologians have some special access to divine truth that is barred to the rest of us? Are theologians the only ones who have to speak rightly about God? Do our scholars and educators perform that role on behalf of the rest of us - as if the church had outsourced its witness to a small group of qualified professionals? Obviously the church as a whole is charged with the responsibility of right speech. The church as a whole is called to address God in prayer and the world in witness. The job description of scholars and educators, therefore, is really just 


\section{"Without libraries} and librarians, we might just forget who we are and

what we have received and what we have to do with that deposit. Without libraries and librarians, the church might forget its calling to be a point of connection between the living and the dead, the future and the past." the job description of the church. And yet the church really needs its theologians. Without them, the church's speech might quickly become lazy and undisciplined. We might forget that speech about God demands a constant sensitivity to language, a loving attention to the way we direct our words back to God and to one another. Christian scholars, then, have no independent importance; they are essential just because the church is essential, and without them we might forget what the church is really all about.

The same holds true for every possible variety of Christian vocation. Every calling, every vocation, is a microcosm of the calling of the whole body of Christ. Ultimately, our vocation is to be the people of God, bearing witness to a new world and a new humanity. And we receive that vocation in an almost infinite variety of callings, each one a little mirror, each a slightly different shape, all reflecting the same image of the whole.

With that in mind, one can draw some theological conclusions about the distinctive Christian vocation of librarianship.

The librarian does not stand alone between past and future, overcoming divisions and making connections. It is the church - the whole people of God - that stands poised between past and future, between the memory of Christ and the hope of his promise. The church is called to cross each barrier that divides the world into isolated fragments. The church is called to be an engine of catholicity, announcing and enacting the glad tidings that in Christ God has put an end to the walls of division, so that all human beings everywhere are called to become one in Christ. The church is called to stand in the gap wherever the world is falling to pieces, since God's action in Christ is catholic and ecumenical in the most comprehensive sense.

Everything that has been said about the vocation of librarians, therefore, needs to be said even more emphatically about the whole people of God. Yet without librarians, the church might easily start to cling to the past as security against an uncertain future; or, alternatively, to imagine that the past is over and done with, that we can direct all our attention to the challenges of the future without preserving continuity with the traditions of the past. On the one hand, a reactionary suspicion of the future, and a belief that faithfulness resides in a mere attachment to the past. On the other hand, a cult of the future, a radical suspicion of structures and institutions, a capitulation to fads, an undiscriminating appetite for the New. On the right and on the left, these are not marginal dangers for the church today; they are powerful temptations, disastrously alluring, beckoning us to shut our ears against the present or the past. Without libraries and librarians, we might just forget who we are and what we have received and what we have to do with that deposit. Without libraries and librarians, the church might forget its calling to be a point of connection between the living and the dead, the future and the past. Libraries and librarians are essential just because the church is essential. In the mirror of the librarian's 
vocation we see reflected back, as in a mirror, a small but vivid image of Christ's calling to the whole people of God.

And that, ultimately, is the mystery of Christian vocation: that in each particular vocation it is Christ who is reflected, Christ who becomes visible. The calling of the people of God is really just a calling to stand where Christ stands and to go where Christ goes. And this is where the joy of Christian vocation will always be found: the joy of being with Christ and being found in him.

"In the mirror of the librarian's

vocation we see reflected back, as in a mirror, a small but vivid image of Christ's calling to the whole people of God."

\section{Bibliography}

Darnton, Robert. "A Digital Library Better Than Google's." The New York Times March 23,2011. http://www.nytimes.com/2011/03/24 /opinion/24darnton.html.

Nicholl, Donald. Triumphs of the Spirit in Russia. London: Darton, Longman and Todd, 1997.

Pelikan, Jaroslav. The Idea of the University: A Reexamination. New Haven: Yale University Press, 1992.

Young, George M. Nikolai F. Federov: An Introduction. Belmont, MA: Nordland Publishing Company, 1979.

Young, George M. The Russian Cosmists: The Esoteric Futurism of Nikolai Fedorov and His Followers. Oxford: Oxford University Press, 2012. 